Article

\title{
Sickle Cell Trait Induces Oxidative Damage on Plasmodium falciparum Proteome at Erythrocyte Stages
}

\author{
Alber Díaz-Castillo ${ }^{1}$, Neyder Contreras-Puentes ${ }^{2} \mathbb{0}$, Ciro Alvear-Sedán ${ }^{3}$, \\ Carlos Moneriz-Pretell ${ }^{3}$, Erika Rodríguez-Cavallo ${ }^{2, *}$ and Darío Mendez-Cuadro ${ }^{1, *(D)}$ \\ 1 Analytical Chemistry and Biomedicine Group, Exacts and Natural Sciences Faculty, University of Cartagena, \\ 130015 Cartagena, Colombia; alberdiazcastillo96@gmail.com \\ 2 Analytical Chemistry and Biomedicine Group, Pharmaceuticals Sciences Faculty, University of Cartagena, \\ 130015 Cartagena, Colombia; neidercontreras11@gmail.com \\ 3 Biochemistry and disease Group, Medicine School, University of Cartagena, 130015 Cartagena, Colombia; \\ calvears@unicartagena.edu.co (C.A.-S.); cmonerizp@unicartagena.edu.co (C.M.-P.) \\ * Correspondence: erodriguezc1@unicartagena.edu.co (E.R.-C.); dmendezc@unicartagena.edu.co (D.M.-C.); \\ Tel.: +57-3015588298 (E.R.-C.); +57-3015584887 (D.M.-C.)
}

Received: 23 August 2019; Accepted: 24 October 2019; Published: 16 November 2019

\begin{abstract}
The presence of hemoglobin A-S (HbAS) in erythrocytes has been related to the high production of reactive oxygen species (ROS) and an increased in intracellular oxidative stress that affects the progress of Plasmodium erythrocytic cycle life and attenuates its serious clinical symptoms. Nevertheless, oxidative effects on P. falciparum proteome across the intraerythrocytic cycle in the presence of $\mathrm{HbAS}$ traits have not been described yet. Here, an immune dot-blot assay was used to quantify the carbonyl index (C.I) on P. falciparum 3D7 proteome at the different asexual erythrocytic stages. Protein carbonylation on parasites cultivated in erythrocytes from two donors with $\mathrm{HbAS}$ increased $5.34 \pm 1.42$ folds at the ring stage compared to control grown in hemoglobin A-A ( $\mathrm{HbAA})$ red blood cells. Whereas at trophozoites and schizonts stages were augmented $2.80 \pm 0.52$ and $3.05 \pm 0.75$ folds, respectively. Besides proteins involved in processes of the stress response, recognition and invasion were identified from schizonts carbonylated bands by combining SDS-PAGE with MALDI-TOF-TOF analysis. Our results reinforce the hypothesis that such oxidative modifications do not appear to happen randomly, and the sickle cell trait affects mainly a small fraction of parasite proteins particularly sensitive to ROS.
\end{abstract}

Keywords: Plasmodium falciparum; asexual stages; sickle cell trait; protein carbonylation; carbonyl index

\section{Introduction}

Malaria is one of the oldest diseases in the world, during the last 70,000 years of co-evolution with humans it has generated a selective pressure on the human genome and produces the appearance of erythrocyte polymorphisms, such as structural and quantitative hemoglobinopathies [1]. These constitute an important health problem, mainly in malaria-endemic areas with a high frequency of individual carriers, not only in their countries of tropical and subtropical origin but globally as a result of the augment of massive human migrations [2].

It has been estimated that $5 \%$ of the world population has genes related to hemoglobinopathies, being sickle cell anemia the most common hemoglobinopathy in the United States, Latin America and the Caribbean $[3,4]$ and the individuals affected can be homozygous (HbSS) or heterozygotes (HbAS). The highest prevalence of the sickle cell trait occurs in equatorial and western Africa reaching 
around $40 \%$. In Latin America, countries as Brazil and Colombia reach a global prevalence between $5-6 \%$ and $6-10 \%$, respectively. Nevertheless, in some geographical regions with a great number of Afro-American populations prevalence exceeds 10\% [3].

Although the beneficial effects of HbAS against clinical symptoms of severe malaria are well accepted, the mechanisms of protection are not completely clarified [5]. Among the biochemical and immune-mediated mechanisms proposed are reduced adherence of parasitized erythrocytes [6], the improvement of the host immune response [7], the arresting of parasite growth [8] and the overexpression of the enzyme heme-oxygenase 1 [9].

Many of these metabolic pathways somehow affect the fine redox balance between parasite and the host $[10,11]$ and could act on specific protein targets involved in several various metabolic processes, such as the remodeling of the host cell membrane and export of proteins parasite Cytoskeletal membrane proteins of $P$. falciparum infected erythrocytes seem particularly susceptible to oxidative damage during infection under glucose-6-phosphate dehydrogenase (G6PD) deficiency and HbAS trait conditions [11,12].

Nevertheless, the oxidative effects caused on the proteome of $P$. falciparum through the intraerythrocytic cycle in the presence of $\mathrm{HbAS}$ trait have not been described yet. Protein carbonylation is considered a major hallmark of oxidative stress-related disorders, and it is one of the most harmful irreversible oxidative protein modifications. Its measurements are often performed to assess the extent of oxidative stress under different contexts of cellular damage [13]. Therefore, the degree of oxidation of the P. falciparum 3D7 proteome was quantified, and potentially carbonylated proteins were identified as a consequence of the presence of the sickle cell trait.

\section{Results}

\subsection{Cultures of P. falciparum 3D7 on HbAS Carriers and Control Donors}

A random sample of 50 healthy donors was assayed to identify carriers of the sickle cell trait. Horizontal hemoglobin electrophoresis was positive for three donors, reaching $6 \%$ prevalence and the $\mathrm{HbAS}$ percentages obtained by the densitometric analysis were $36.4 \%$ (JT-donor), 41.7\% (HH-donor) and $43.0 \%$ (MJ-donor; Figure 1).

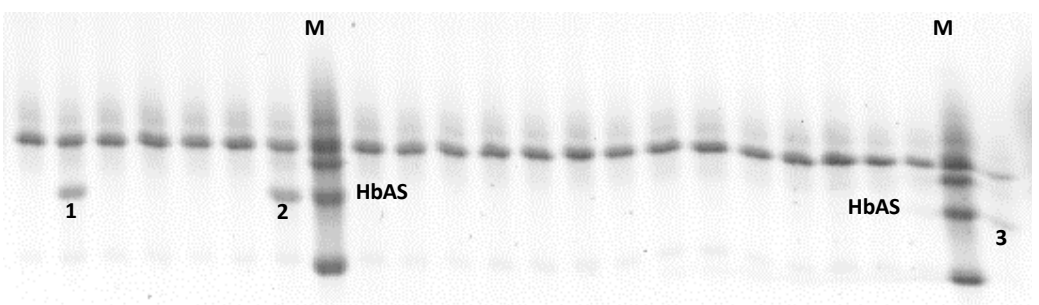

Figure 1. Horizontal hemoglobin electropherogram for the identification of $\mathrm{HbAS}$ carriers. Numbered bands show the presence of hemoglobin S (HbAS) for JT (1), HH (2) and MJ (3) donors, respectively. $\mathrm{M}: \mathrm{Hb}$ marker.

Synchronous cultures of $P$. falciparum were harvested at rings, trophozoites and schizonts stages for each donor, three $\mathrm{HbAS}$ and a control $\mathrm{HbAA}$. Around $800 \mu \mathrm{L}$ were collected with parasitemias in a range of $34-40 \%$ as showed in Figure 2. Details about harvested cultures are summarized in Supplementary Table S1. Any morphological differences between $\mathrm{HbAA}$ and $\mathrm{HbAS}$ cultures were not observed during the progression of the parasite erythrocytic cycle.

Next, cultures were lysed with a sorbitol solution to obtain the fraction of infected red blood cells (iRBCs) membrane proteins, which were used in other studies [11]. Then, pellets were treated with sample buffer (Tris- $\mathrm{HCl} 50 \mathrm{mM} \mathrm{pH} \mathrm{8,} \mathrm{NaCl} 50 \mathrm{mM}$ and SDS 1\%) to obtain parasite proteins in a range of $0.6-2.3 \mu \mathrm{g} / \mu \mathrm{L}$, which were used to subsequently assays (see Supplementary Table S2). 

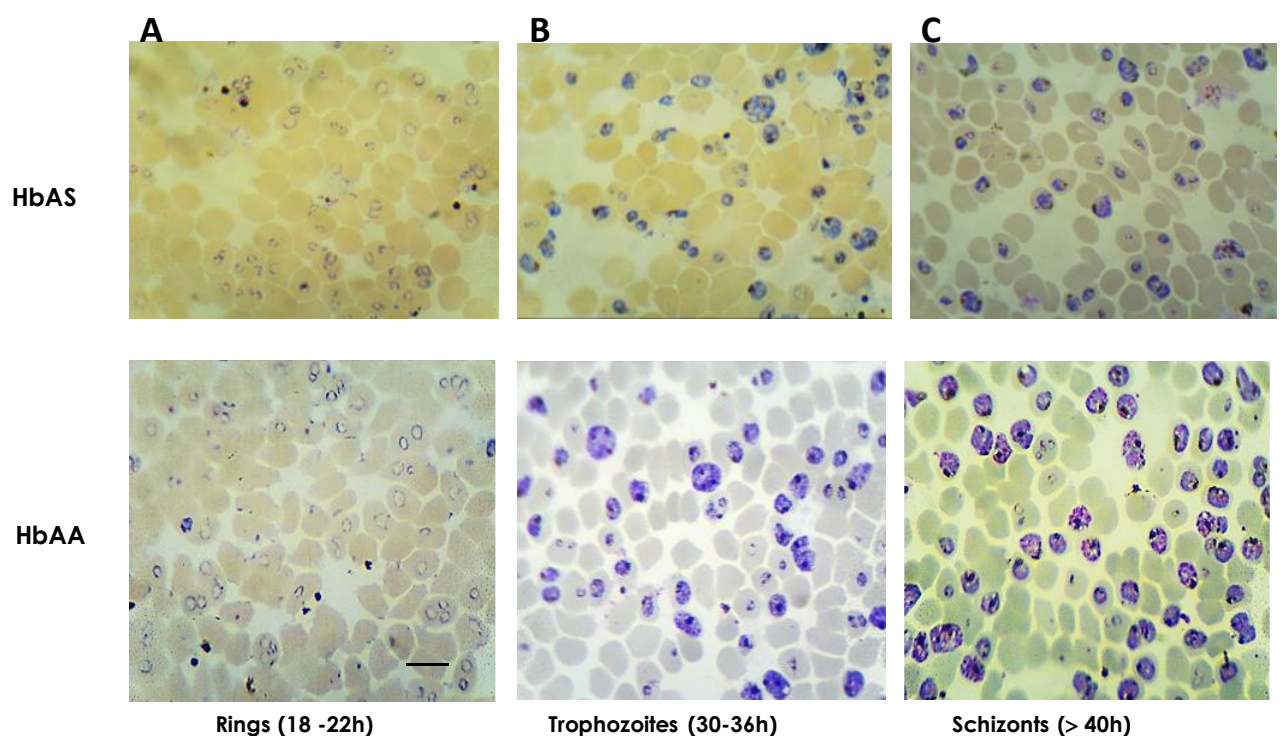

Figure 2. Synchronous cultures of $P$. falciparum 3D7 asexual stages. Parasites were grown in HbAA and $\mathrm{HbAS}$ red blood cells (RBCs). Asexual typical forms were harvested for different stages. (A). Late rings (14-20 h), (B). mature trophozoites (30-36 h) and (C). schizonts ( $>40 \mathrm{~h})$. Smears were stained with Giemsa $10 \%$ and magnified $100 \times$. Scale bar $=10 \mu \mathrm{m}$.

\subsection{Quantitation of Carbonyl Index by Dot-Blot}

Linearity, repeatability, and reproducibility were assayed for the carbonylated proteins calibration curve. Calibration curve of bovine serum albumin (BSA) shown linearity for a range of carbonyl index values between 0.8 to $17.7 \mathrm{nmol}$ carbonyl/mg proteins $\left(\mathrm{R}^{2}>0.997\right.$, see Figure 3$)$. Repeatability was assayed with curves built on the same day, whereas reproducibility was calculated with data of two different days. RSDs obtained were lower than $1.3 \%$ for slope values of the curves constructed, establishing that no statistical differences were found $(p<0.05)$. Raw data used to evaluate repeatability, and reproducibility is provided in Supplementary Table S3, and Supplementary Figure S1.
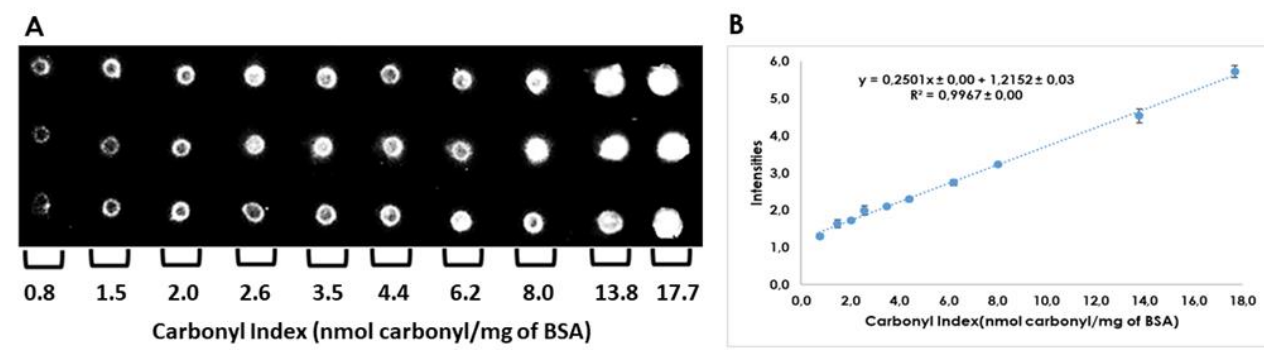

Figure 3. Calibration curve of carbonylated proteins for quantitation of carbonyl indexes by dot-blot. (A). $2 \mu \mathrm{L}$ of DNPH derivatized bovine serum albumin (BSA; $100 \mathrm{ng} / \mu \mathrm{L}$ ) from standard working solutions were spotted by triplicate on PVDF membranes. (B). Mean from three calibration curves analyzed in two different days. The calibration curve was derived from reproducibility assay.

Next, carbonyl indexes were determined for $P$. falciparum proteins from parasites grown in $\mathrm{HbAA}$ and $\mathrm{HbAS}$ red blood cells (RBCs). Oxy dot-blots obtained are showed in Supplementary Figure S2 and carbonyl index data are summarized in Table 1. 
Table 1. Carbonyl index of P. falciparum proteins at different asexual stages in $\mathrm{HbAA}$ and $\mathrm{HbAS}$ erythrocytes.

\begin{tabular}{ccccc}
\hline \multirow{2}{*}{ Condition } & \multirow{2}{*}{ Patients } & \multicolumn{2}{c}{ C.I. (nmol of Carbonyls/mg of Protein) } \\
\cline { 3 - 5 } & & Rings & Trophozoites & Schizonts \\
\hline HbAA & NC & $12.7 \pm 1.07$ & $24.9 \pm 0.83$ & $21.4 \pm 0.95$ \\
\hline \multirow{2}{*}{$\mathrm{HbAS}$} & $\mathrm{ST}$ & $88.0 \pm 2.10$ & $84.9 \pm 2.15$ & $83.9 \pm 2.23$ \\
\cline { 2 - 5 } & $\mathrm{MC}$ & $62.6 \pm 1.04$ & $59.7 \pm 0.92$ & $55.6 \pm 1.29$ \\
\cline { 2 - 5 } & $\mathrm{MJ}$ & $53.1 \pm 1.99$ & $66.3 \pm 2.56$ & $56.3 \pm 3.00$ \\
\hline
\end{tabular}

Carbonyl index (C.I.) values calculated and expressed as means \pm SD. Dilutions 1/10 in PBS of parasite proteins were required in those samples with C.I.s upper than $18 \mathrm{nmol}$ of carbonyls/mg of protein.

For parasites grown in control $\mathrm{HbAA}$ erythrocytes, protein carbonylation increased with the progress of parasite cycle life, being greater at trophozoites and schizonts than in the ring stages; whereas parasites grown in $\mathrm{HbAS}$ cells showed a significant increase of carbonyl indexes from early ring stage.

To measure the variation of oxidative damage suffered by proteome parasites, the carbonyl index quotient $\mathrm{HbAS} / \mathrm{HbAA}$ was calculated. Thus, for example, carbonyl index for normal $\mathrm{HbAA}$ iRBCs at ring stage was $12.7 \pm 1.07 \mathrm{nmol}$ of carbonyls/mg of parasite proteins; whereas HbAS donor with code ST reached $88.0 \pm 2.10 \mathrm{nmol}$ of carbonyls/mg of protein. The quotient $88.0 / 12.7$ indicates an increment of 6.92 folds on the irreversible oxidative damage suffered by parasite proteins when it is cultured in $\mathrm{HbAS}$ erythrocytes. Individual quotients for all samples are summarized in Table 2, and the behavior of these data appears plotted in Supplementary Figure S3.

Table 2. Relative increasing in carbonyl index on the proteome of $P$. falciparum cultured in HbAS RBCs.

\begin{tabular}{ccccc}
\hline \multirow{2}{*}{ Condition } & \multirow{2}{*}{ HbAS/HbAA } & \multicolumn{3}{c}{ C.I. HbAS/CI HbAA } \\
\cline { 3 - 5 } & & Rings & Trophozoites & Schizonts \\
\hline \multirow{2}{*}{$\mathrm{HbAS}$} & $\mathrm{ST} / \mathrm{NC}$ & 6.92 & 3.38 & 3.93 \\
\cline { 2 - 5 } & $\mathrm{MC} / \mathrm{NC}$ & 4.92 & 2.38 & 2.60 \\
\cline { 2 - 5 } & $\mathrm{MJ} / \mathrm{NC}$ & 4.18 & 2.64 & 2.64 \\
\hline \multicolumn{2}{c}{ Means $\pm \mathrm{SD}$} & $5.34 \pm 1.42$ & $2.80 \pm 0.52$ & $3.05 \pm 0.75$ \\
\hline
\end{tabular}

C.I.s: Carbonyl indexes can be observed there, in all cases, carbonyl indexes of parasites proteome were augmented in erythrocytes with the sickle cell trait. Furthermore, during the ring stage was recorded the largest oxidative increment being 1.9 folds and 1.75 folds greater than reached in trophozoites and schizonts stages. Therefore, our data show a particular susceptibility to protein oxidative stress at an early asexual stage of rings in the presence of this severe malaria protector polymorphism.

\subsection{Determination of P. falciparum Protein Carbonylation Patterns on HbAA and HbAS Carriers}

Qualitative profiles of carbonylated proteins of P. falciparum were obtained at the rings, trophozoites, and schizonts stages in samples of control $(\mathrm{HbAA})$ and $\mathrm{HbAS}$ carriers. Results obtained show a wide and intense protein carbonylated band around $50 \mathrm{kDa}$ in all donors with $\mathrm{HbAS}$ that appears as a weak double band for HbAA control (Figure 4). This pattern was kept constant across the different parasite asexual stages. 


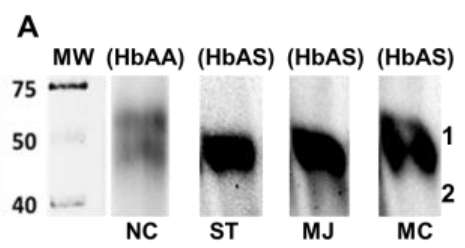

B
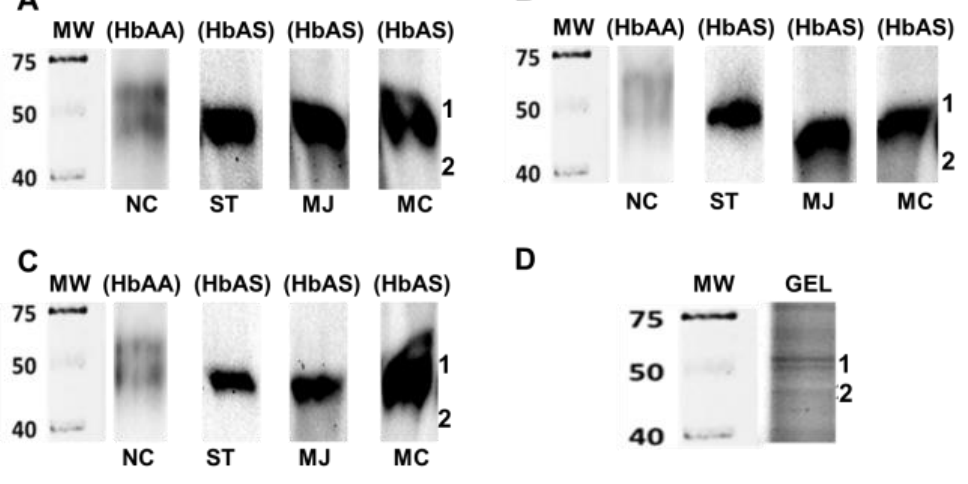

D

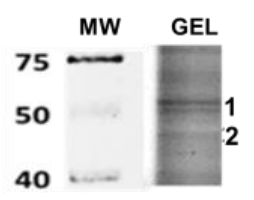

E

Rings
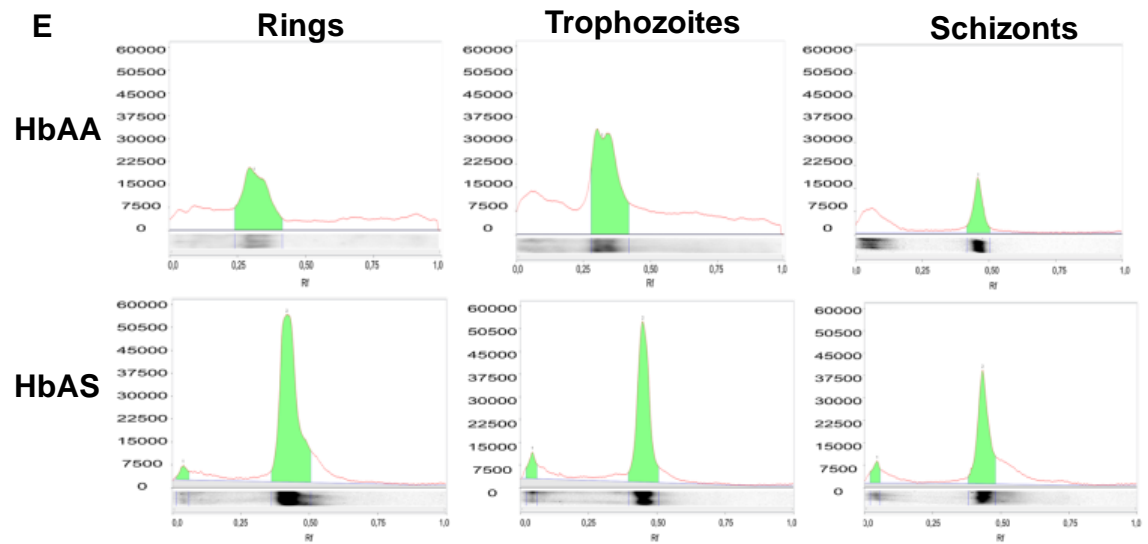

Figure 4. Profile of $P$. falciparum protein carbonylated bands at different asexual stages. Panels show protein oxidized profiles obtained at rings (A), trophozoites (B) and schizonts (C) from HbAS control and HbAS carriers. NC: HbAA control. ST, MC, and MJ: HbAS donors. Panel D shows the preparative polyacrylamide gel stained with Coomassie Blue Brilliant (CBB) for schizont's proteins that match with the oxyblots. Of parasite proteins $2.5 \mu$ g derivatized with DNPH were used in oxyblots, while $50 \mu \mathrm{g}$ were electrophoresed in preparative SDS-PAGE. Panel E displays densitograms of carbonylated protein bands detected in oxyblots across the erythrocytic cycle for HbAA control and ST HbAS donor. Densitograms were analyzed with ImageLab software ${ }^{\circledR}$ to determine variations in the intensity of the signal for the detected carbonylated bands (panel E, Figure 4). For parasite proteins from erythrocytes, HbAA recorded the trophozoites stage as the most oxidizing, while the ring stage was the more carbonylated phase in $\mathrm{HbAS}$ proteins. This behavior reinforces the result obtained previously by dot-blot.

In a similar way to carbonyl indexes, the quotients $\mathrm{HbAS} / \mathrm{HbAA}$ were calculated for carbonylated bands and plotted in Figure 5. Data of adjusted intensities are listed in Supplementary Tables S5 and S6. Results obtained, again support the presence of increased oxidative damage from the ring stage, associate with the presence of the sickle cell trait. 

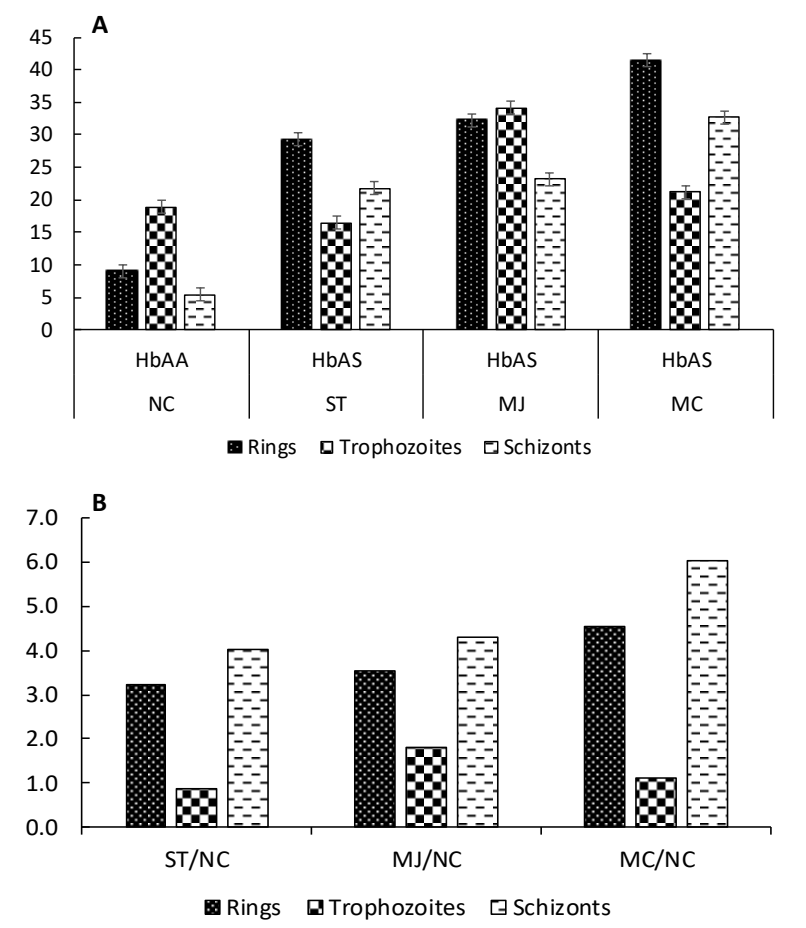

Figure 5. Intensities of $P$. falciparum proteins carbonylated bands across asexual stages. In panel $\mathbf{A}$ is shown individual intensity values for carbonylated bands by donors and erythrocytic stage; while in panel B is plotted the quotients $\mathrm{HbAS} / \mathrm{HbAA}$.

\subsection{Identification of Proteins in Carbonylated Bands}

Finally, three protein bands in Coomassie Blue Brilliant (CBB) stained gel matched with the carbonylated bands observed in oxyblots (Figure 4). The first and second bands appeared as double and were numbered 1.1 and 1.2; while the last one was numbered 2. Bands were excised from rings and schizonts lanes gel and processed as was above mentioned. Mixtures of parasite and human proteins were identified by MS/MS analysis only in schizonts bands, and they are listed in Table 3 . No parasite protein bands were identified from rings, and the human ones detected were coincident with those identified in schizonts.

\section{Discussion}

Erythrocyte redox balance is found permanently disturbed in erythrocytes harboring hemoglobin S. In the case of sickle cell disease (HbSS), clinical cumulative effects are intimately linked to a chronic and systemic oxidative stress [14]. While in its heterozygous form (HbAS), the altered status redox is part of the uncomfortable environmental conditions for the free development of Plasmodium gender parasites and involves the activation of multiple cellular mechanisms of resistance to clinical severe symptoms of the infection [15].

In this sense, Archer has proposed a protector mechanism, based on $\mathrm{HbAS}$ polymerization in infected RBCs with low $\mathrm{O}_{2}$ concentrations, due to its capability to arrest in vitro parasite growing [15]. Nevertheless, $\mathrm{HbAS}$ polymerization is a reversible process by agents as $\mathrm{CO}$ and $\mathrm{CO}_{2}$ and hence the growth of the parasite could be restored in the presence of these gases $[15,16]$. In our culture conditions, parasites were maintained at $5 \% \mathrm{CO}_{2}$ and the hematocrit kept low by medium changes according to the method of Radfar [17], which may explain why we do not observe alterations in the progression of the parasite cycle life in $\mathrm{HbAS}$ erythrocytes.

Oxidative stress, on the other hand, is one of the body's important defensive immune mechanisms during malaria infection, affecting its progress and clinical outcome. Thus, for example, the high and rapid production of ROS during the acute phase of infection may be beneficial to reduce parasitemia [18]. 
Oxidative stress induced by antimalarial agents, as chloroquine and artemisinin, is also important in malaria parasite clearance. Nevertheless, chronic stimulation of ROS or its excessive production, are deleterious to the host cells and favors massive hemolysis with eventual metabolic acidosis and respiratory distress $[18,19]$.

Table 3. Proteins identified in carbonylated bands.

\begin{tabular}{|c|c|c|c|c|c|}
\hline Band & Identification & Mass (Da) & Score & Name Submission & Biology Process \\
\hline \multirow{4}{*}{1.1} & B3AT_HUMAN & 102,013 & 130 & $\begin{array}{l}\text { Anion transport protein, } \\
\text { band } 3\end{array}$ & Anion and ion transport \\
\hline & BB_HUMAN & 16,102 & 82 & $\begin{array}{l}\text { Hemoglobin subunit } \\
\text { beta }\end{array}$ & Oxygen transport \\
\hline & PF3D7_0501600 & 43,672 & 112 & $\begin{array}{l}\text { Rhoptry-associated } \\
\text { protein } 2\end{array}$ & Entrance to the host cell \\
\hline & gi|11125364 & 55,782 & 56 & $\begin{array}{c}\text { Protein disulfide } \\
\text { isomerase (Plasmodium } \\
\text { falciparum) }\end{array}$ & $\begin{array}{l}\text { Protein folding, Cell } \\
\text { redox homeostasis, and } \\
\text { response to endoplasmic } \\
\text { reticulum stress }\end{array}$ \\
\hline 1.2 & B3AT_HUMAN & 102,013 & 274 & $\begin{array}{l}\text { Anion transport protein, } \\
\text { Band } 3\end{array}$ & Anion and ion transport \\
\hline \multirow{4}{*}{2} & HBB_HUMAN & 16,102 & 201 & $\begin{array}{l}\text { Hemoglobin subunit } \\
\text { beta }\end{array}$ & Oxygen transport \\
\hline & gi|160112 & 33,774 & 62 & $\begin{array}{c}\beta \text {-galactosidase, partial } \\
\quad(P . \text { falciparum })\end{array}$ & $\begin{array}{c}\text { Metabolic process of } \\
\text { cellular carbohydrates } \\
\text { Catabolic galactose } \\
\text { process }\end{array}$ \\
\hline & gi|160537 & 27,813 & 64 & $\begin{array}{l}\text { Surface protein } \\
\text { (P. falciparum) }\end{array}$ & Pathogenesis \\
\hline & gi|124512406 & 74,382 & 57 & $\begin{array}{c}\text { Heat shock } 70 \mathrm{kDa} \\
\text { protein (P. falciparum } \\
\text { 3D7) }\end{array}$ & $\begin{array}{l}\text { Stress response, ATP } \\
\text { metabolic process, } \\
\text { cellular response to } \\
\text { oxidative stress }\end{array}$ \\
\hline
\end{tabular}

Despite this background, the oxidative damage suffered by P. falciparum parasites as a consequence of metabolic conditions resident in erythrocytes with $\mathrm{HbAS}$ has not been quantified and characterized yet.

Thus, we calculated the degree of protein oxidation on the P. falciparum proteome in vitro during their asexual phase in erythrocytes carrying the sickle trait employing a quantitative dot-blot assay. For this, donors with $36.4-43.0 \%$ of $\mathrm{HbAS}$ were identified by horizontal hemoglobin electrophoresis. A $6 \%$ prevalence was calculated in our random sample, establishing in the range of $5-10 \%$ reported for some regions of the Colombian territory $[20,21]$. Next, parasites were cultured and processed to obtain proteomes at ring, trophozoites and schizonts stages. Repeatability and reproducibility of the protein carbonylated calibration curve proved to be suitable for the quantification of carbonyl indexes and the evaluation of the oxidative damage suffered by the P. falciparum proteome throughout its asexual life cycle. The behavior of the calibration curve was like those reported previously [11,22].

Results obtained for control $\mathrm{HbAA}$ showed low carbonyl indexes during the ring stage, a maximum of oxidative response in trophozoites, followed by a little decrease during the schizont stage. This behavior is congruent with the development of the parasite, which shows maximum metabolic activity during the trophozoite stage. In this period the parasite consumes hemoglobin and releases pro-oxidant products derived from free heme [23,24]; however, $P$. falciparum prevents its deleterious effects by increasing of their efficient antioxidant systems, such as the GluPho enzyme that corresponds to the combination of the G6PD of the parasite with the second enzyme of the pathway of the pentoses, 6-phosphogluconolactonase (PfG6PD-6PGL) [25,26].

Under conditions of $\mathrm{HbAS}$ trait, the behavior of the carbonyl indexes of the proteome of P. falciparum evidenced substantial changes. In all stages, the oxidative damage increased compared to control, 
being largest at the ring stage where it was 5.34 times larger than in control, while it was only almost twice as large in trophozoites and schizonts. We have previously measured the particular increase in oxidative stress occurring in the ring stage and how it mainly affects the host cell membrane proteins in protective red cell polymorphisms of severe malaria, such as G6PD deficiency, blood group O and $\mathrm{HbAS}[11,12,27]$. Susceptibility of host proteins to oxidative stress during the ring stage would be related to the low expression described for the main antioxidant enzymes and heat shock proteins of the parasite [28]. These sets of evidence indicate that the biochemical mechanisms operate through irreversible oxidative damage, and confer advantages to $\mathrm{HbAS}$ carrier concerning severe malaria symptoms, occurring or beginning at the early ring stage and affecting the host cell proteins.

Although at trophozoites and schizonts stages, carbonyl indexes decreased in parasites grown in $\mathrm{HbAS}$ erythrocytes compared to rings stage, the oxidative damage on parasite proteome is still larger than those observed in parasites cultured in control HbAA RBCs. This behavior is consistent with some antioxidant mechanisms associated with the pentose phosphate pathway that increases its activity during trophozoites, decreases in the schizont stage but maintains an activity increased 10 times greater than during the early stages of the parasite [29]. This route is fundamental due to its function in the synthesis of nucleotides and the reduction of nicotinamide adenine dinucleotide phosphate (NADP) to nicotinamide adenine dinucleotide phosphate reduced (NADPH).

Therefore, quantitation of the carbonyl index of the parasite proteome seems to be a good marker to measure the oxidative changes on P. falciparum proteome across the intraerythrocytic cycle under different genetic backgrounds or cultured conditions.

On the other hand, analysis of protein carbonylated profiles obtained by Western blot in our conditions showed oxidative damage focused, constant and limited to a reduced size zone for the parasite proteome during all asexual stages. This finding is similar to the one found by Radfar, who described a series of carbonylated proteins that remained nearly constant throughout the life cycle of P. falciparum clone Dd2 in control samples not exposed to chloroquine [19] and reinforce that such modifications do not appear to happen randomly [30]. Herein, our results indicate that the pro-oxidant environment residing in $\mathrm{HbAS}$ erythrocytes only increases the intensity of the oxidative damage for those small fractions of parasite proteins particularly sensitive to ROS.

Five schizonts parasite proteins were identified into this group along with the erythroid band-3 and hemoglobin, which indicates a good performance for the parasite protein obtention method applied due to a reduced presence of host cell proteins. Two identified parasite proteins, heat shock 70 and disulfide isomerase, are chaperones involved in the metabolic pathways of the stress response; while beta-galactosidase is a glycolytic enzyme involved in the process of catabolic galactose. These parasite proteins make part of the macromolecule networks involved in the adaptation of P. falciparum to hyperoxic stress and were classified by Radfard as highly susceptible to oxidative damage $[19,30]$. Besides, it should be taken into account that $2 \%$ of the parasite genome encodes chaperone proteins playing diverse important roles in the development of the parasite [31].

In the case of rhoptry-associated protein 2 (RAP-2), it is ubicated within the rhoptries of Plasmodium falciparum forming a low molecular weight complex along to RAP-1 and RAP-3. These merozoite proteins play an important role in erythrocyte invasion [32]. They have functions of protease, integral membrane protein, erythrocyte-binding protein and domain oxidoreductase and participate in the initial recognition and generation of the parasitophorous vacuole and the modification of the host cell [33]. Other protein involved in erythrocyte invasion was identified in carbonylated bands, the P. falciparum surface protein, which is related to the heat shock $70 \mathrm{KDa}$ [34]. Composition and function of merozoite surface proteins (MSPs) and rhoptries has been of great interest either role in RBC invasion and potential as vaccine candidates [33] but how they are affected by oxidative posttranslational modifications is something not revealed yet.

Finally, host cell protein band 3 is a glycoprotein in the erythrocyte membrane, which carries out the exchange of chloride/bicarbonate, a process necessary for cellular respiration [35]. The oxidation of band-3 causes its clusterization and disruption of their complexes with other proteins as cytoskeletal 
ankyrin [36]. Clusterization can be also promoted by binding of hemoglobin by-products (hemichromes) to the cytoplasmic domain of band-3. Thus, eliciting the humoral immune response to remove the affected red blood cells from the circulation [10,37]. In fact, Band 3 had been identified as carbonylated in P. falciparum infected erythrocytes with other protector polymorphism of severe malaria $[11,27]$.

Overall, any irreversible posttranslational modification as carbonylation could affect the structure and functionality of proteins. In particular, it has been demonstrated that direct carbonylation of lateral chains of lysine and arginine residues is equivalent to replacing a hydrophilic residue with a hydrophobic one, which by itself significantly increases the intrinsic aggregation propensity of the protein [38]. More recently, we showed how the indirect carbonylation with 4-hydroxy-2-nonenal induces structural local changes and disturbs the conformational stability, folding and flexibility of oxidized proteins, increasing its lipophilic potential and altering their electrostatic potential [39]. Although we did not discriminate between direct and indirect carbonylation, our results reinforced the participation of protein carbonylation as mediators in mechanisms of resistance to severe malaria in the sickle cell trait.

\section{Materials and Methods}

\subsection{Identification of Donor's Hemoglobin S Carriers}

Hemoglobin S (HbAS) from voluntary donors was identified by horizontal hemoglobin electrophoresis. All donors gave their informed consent for inclusion before they participated in the study, and the protocol was approved by the Ethics Committee of the University of Cartagena (Project Actas 013-2017/ 011-2017, 16-05-2017. First, the capillary blood samples were placed on filter paper (Whatman 1), deposited in a 96 well microplate, with the addition of an elution solution for $30 \mathrm{~min}$. Then, the electrophoresis cabinet (Migele Gel Electrophoresis Unit, PerkinElmer, 940 Winter Street, Waltham, MA, USA) was prepared by placing a strip in the center, and two strips on the sides (right and left); the strips were previously embedded in anodic, and cathodic solutions, respectively. Subsequently, $1 \%$ agarose (Sigma, St Louis, MO, USA) gel was added, samples were loaded and electrophoresed at $120 \mathrm{~V}$ for $90 \mathrm{~min}$. After electrophoresis, the gel was submerged in 30\% TCA (Sigma) for $5 \mathrm{~min}$, followed by washing with Mili-Q water and drying overnight. The identification of $\mathrm{HbAS}$ carriers was based on the Rf with the $\mathrm{Hb}$ marker provided in the commercial kit of neonatal hemoglobin RESOLVE $^{\circledR}$ (PerkinElmer, 940 Winter Street, Waltham, MA, USA). The percentage of Hb expression was measured by density analysis with the Quantity One software (BioRad, Hercules, CA, USA).

\subsection{Plasmodium falciparum $3 D 7$ Cultures and Parasite Protein Obtention}

P. falciparum clone 3D7 was gifted by Dr. Sara Robledo from the PECET group of the University of Antioquia. Synchronous cultures of $P$. falciparum 3D7 with high parasitemia were grown by triplicates in RBCs from control and three HbAS donors, following strictly the protocol previously described by Radfar [17]. Synchronization was based on sorbitol 5\% (Sigma) and Percoll 90\% (GE Healthcare, Pittsburgh, PA, USA) methods; the progress of asexual stages was monitored by stained smears with Giemsa 10\% (Merck, St Louis, MO, USA). Infected red blood cells (iRBCs) at rings, trophozoites and, schizonts stages were harvested from each donor and finally stored at $-40{ }^{\circ} \mathrm{C}$ until processing. Samples were treated individually for all subsequent assays.

The parasite proteins were obtained by combining two protocols previously described. First, iRBCs at trophozoites and schizonts stages were lysed with $5 \%$ sorbitol solution for $10 \mathrm{~min}$ at $37^{\circ} \mathrm{C}$ and subsequently centrifuged at $2300 \mathrm{rpm}$ and $4{ }^{\circ} \mathrm{C}$. This procedure was repeated several times until obtaining a colorless supernatant [27]. Second, ring iRBCs were incubated 5 min with saponin $0.05 \%$ (Sigma) at room temperature, centrifuged $14,000 \times g$ for $10 \mathrm{~min}$ at $4{ }^{\circ} \mathrm{C}$ and washed three times with ice-cold PBS, followed by one wash in $10 \mathrm{mM}$ Tris-HCl, pH 7.4 (Sigma) [19]. Finally, parasite pellets were homogenized in sample buffer (Tris- $\mathrm{HCl} 50 \mathrm{mM} \mathrm{pH} \mathrm{8,} \mathrm{NaCl} 50 \mathrm{mM}$ and SDS 1\%) using four 
cycles of freezing and thawing steps. Samples were centrifuged at $4{ }^{\circ} \mathrm{C}$ to obtain supernatants rich in parasite proteins, which were quantified and stored at $-40{ }^{\circ} \mathrm{C}[40]$.

\subsection{Carbonyl Index Quantitation of Parasite Protein Fractions}

Spectrophotometry and immune dot-blot methods were applied to measure the carbonyl index. For this purpose, an aliquot of the BSA fatty acid-free solution ( $5 \mu \mathrm{g} / \mu \mathrm{L}$, Sigma) was derivatized with a $\mathrm{DNPH}$ probe, and their carbonyl index was measured in alkaline medium at $450 \mathrm{~nm}$ [41]. Its value corresponds to the basal carbonyl index in our conditions (non-oxidized BSA). In parallel, an aliquot of the BSA solution was oxidized with $10 \mathrm{mM} \mathrm{FeSO}_{4}$ by incubation at $37^{\circ} \mathrm{C}$ for $2 \mathrm{~h}$. In both cases, basal and oxidized derived BSA was precipitated with $10 \%$ TCA for $15 \mathrm{~min}$ and the pellets obtained were washed with $85 \%$ acetone for $30 \mathrm{~min}$ and centrifuged at $4{ }^{\circ} \mathrm{C}, 7000 \mathrm{rpm}$ for $5 \mathrm{~min}$. Supernatants were discarded, and the pellets were dissolved in PBS. Subsequently, oxidized and non-oxidized (basal) BSA solutions were quantified with the Bradford assay for normalization at $1 \mu \mathrm{g} / \mu \mathrm{L}$ [40], and quantification of the carbonyl index values by the alkaline medium at $450 \mathrm{~nm}$.

Next, stoichiometric mixtures of the standard proteins (oxidized and basal) were completed to obtain standards solutions with intermediates carbonyl index values. These standard solutions were used to build the protein carbonylated calibration curve of the dot-blot assay. For its purpose, all standards solutions were derivatized using $6 \%$ SDS for $2 \mathrm{~min}$ and $10 \mathrm{mM} \mathrm{DNPH} \mathrm{in} 2 \mathrm{~N} \mathrm{HCl}$ for $10 \mathrm{~min}$, and the reaction was stopped by employing Tris/Glycerol supplemented with $\beta$-mercaptoethanol 85:15 [22,42] ( all reagents from Sigma).

Afterward, $200 \mathrm{ng}$ of each standard were spotted by triplicate on the PVDF membrane (GE Healthcare, Pittsburgh, PA, USA), blocked with PBS-5\% milk for $2 \mathrm{~h}$, incubated with Anti-DNP primary antibody (Merck) (1:5000) for $2 \mathrm{~h}$, followed by incubations with Anti-Rabbit secondary antibody (Thermo Fischer Scientific, Burlington, ONT, Canada) (1:5000) for $1 \mathrm{~h}$.

Membranes were washed with PBS-Milk-Tween 20, PBS-milk and PBS for $5 \mathrm{~min}$ and revealed by chemiluminescence using Kit-Nova for 3 min [11]. The images were captured by a ChemiDoc System (Biorad, Hercules, CA, USA) and the intensity of the spots was analyzed using the Image Lab 6.0 software (Biorad). Replicates were built at different days to evaluate repeatability, reproducibility and linearity of carbonylated protein calibration curves.

To quantify carbonyl index values in samples from parasite proteins at different stages (rings, trophozoites and schizonts), they were DNPH-derivatized, diluted ten folds in PBS, spotted on PVDF membranes, and incubated with the antibodies replicating the methodology described above.

Data were analyzed with GraphPad Prism 6.0 (GraphPad, San Diego, CA, USA) and presented as the mean \pm standard error. C.I.s data, repeatability and reproducibility were analyzed by Student's $t$-test using the parametric test in one-tailed. Statistical significance between groups was established at $p<0.05$.

\subsection{Determination of Carbonylation Patterns on P. falciparum 3D7 Proteins}

To study the oxidative damage suffered by P. falciparum 3D7 across the intraerythrocytic cycle in HbAS RBCs, parasite proteins DNPH-derivatized $(2.5 \mu \mathrm{g})$ were electrophoresed on $10 \%$ SDS-PAGE at 90 and $120 \mathrm{~V}$ for $150 \mathrm{~min}$ (Miniprotean tetracell, Biorad, Hercules, CA, USA). Gels were transferred 30 min on PVDF membranes employing a semi-dry Trans-Blot turbo transfer apparatus (Biorad, Hercules, CA, USA). PVDF membranes were blocked for $2 \mathrm{~h}$ at room temperature with $5 \%$ nonfat dry milk in PBS. Then, membranes were incubated with rabbit polyclonal anti-DNPH antibodies (Merck, St Louis, MO, USA) at 1:5000 in PBS-milk 5\%, for $2 \mathrm{~h}$ at room temperature with gentle rocking, followed by incubation with peroxidase-linked anti-rabbit IgG antibody (Thermo Fischer Scientific, Burlington, ONT, Canada) at 1:5000 for $1 \mathrm{~h}$ at room temperature. Chemiluminescence signals were developed as was mentioned for the dot-blot assay. 
Preparative SDS-PAGE, loaded with $50 \mu \mathrm{g}$ by lane, were run at the same conditions and stained with Coomassie Blue Brilliant (CBB) following a general protocol [12]. Next, they were matched against oxyblots to select protein carbonylated bands.

\subsection{Identification of P. falciparum 3D7 Proteins by Mass Spectrometry}

The carbonylated protein bands selected for MS analysis were reduced in gel, alkylated and digested with trypsin according to Sechi et al. [43]. Briefly, samples were reduced with $10 \mathrm{mM}$ DTT in $25 \mathrm{mM} \mathrm{NH}_{4} \mathrm{HCO}_{3}$ for $30 \mathrm{~min}$ at $56^{\circ} \mathrm{C}$ and subsequently alkylated with $55 \mathrm{mM}$ iodoacetamide in $25 \mathrm{mM}$ ammonium bicarbonate for $15 \mathrm{~min}$ in the dark. Finally, samples were digested with $12.5 \mathrm{ng} / \mathrm{\mu L}$ sequencing grade Bovine Trypsin (Roche Molecular Biochemicals, Penzberg, Germany) in $25 \mathrm{mM}$ $\mathrm{NH}_{4} \mathrm{HCO}_{3}$ (pH 8.5) overnight at $37^{\circ} \mathrm{C}$.

After digestion, the supernatant was collected, and $1 \mu \mathrm{L}$ was spotted onto a MALDI target plate and allowed to air-dry at room temperature. Then, $0.8 \mu \mathrm{L}$ of a $3 \mathrm{mg} / \mathrm{mL}$ of an $\alpha$-cyano-4-hydroxy-cinnamic acid matrix (Sigma) in 50\% acetonitrile $0.1 \%$ TFA were added to the dried peptide and allowed again to air-dry at room temperature.

MALDI-TOF-TOF analysis, was performed at the Proteomics Unit at Complutense University of Madrid, employing a tandem mass spectrometer, 4800 Plus Proteomics Analyzer MALDI-TOF-TOF (Applied Biosystems, MDS Sciex, Toronto, Canada) equipped with a Nitrogen laser diode-pumped $\mathrm{Nd}$ : YAD $355 \mathrm{~nm}$, delayed extraction and reflector, in positive-ion reflector mode (the ion acceleration voltage was $20 \mathrm{kV}$ to MS acquisition and $1 \mathrm{kV}$ to MS/MS). Obtained spectra were stored into the ABI 4000 Series Explorer Spot Set Manager, peptide mass fingerprint (PMF) and MS/MS fragment ion spectra were smoothed and corrected to zero baselines. Protein identification was performed by peptide fingerprint combined with MS/MS using the MASCOT version 2.3 search engine via Global Protein Server (GPS) version 3.6 (ABSCIEX), using SwissProt (553,231 sequences; 197,953,409 residues) and NCBInr databases $(17,919,084$ sequences; $6,150,218,869$ residues) with taxonomic restriction to Homo sapiens (19,179 sequences) and Plasmodium falciparum (19,026 sequences), respectively. Search parameters included: trypsin and carbamidomethylation of cysteines as a fixed modification, oxidation of methionines as a variable modification, error tolerance for the precursor mass of 50 to $100 \mathrm{ppm}$ and tolerance in the masses of the MS (MS) of 0.3 Da.

The identified proteins exceeded the score estimated by the MASCOT MOWSE algorithm so that matches are not due to chance with a probability lower than $5 \%$ and, therefore, be statistically significant with a $p$-value $<0.05$. The fragmented peptides also exceeded the individual ion score that determines MASCOT as significance with a $p$-value $<0.05$ (See Supplementary Material 2).

\section{Conclusions}

Oxidative damage to the proteome of the 3D7 P. falciparum clone cultivated in vitro with erythrocytes harboring the sickle cell trait has been quantified. Protein carbonyl index was used as a marker to demonstrate that irreversible oxidative damage increase with the progressing of asexual cycle life in HbAA RBCs and how it is augmented remarkable at the ring stage for parasites cultured in $\mathrm{HbAS}$ erythrocytes. The data obtained were added to others previously described and indicate that the biochemical protective mechanisms operating through irreversible oxidative damage in the parasite proteome and confer advantages to HbAS occurred or began from the early ring stage. Finally, our results reinforced the hypothesis that such oxidative modifications did not appear to happen randomly, and the sickle cell trait affected mainly a small fraction of parasite proteins particularly sensitive to ROS, such as those identified and involved in processes of recognition, invasion of erythrocytes and stress response.

Supplementary Materials: Supplementary Materials can be found at http://www.mdpi.com/1422-0067/20/22/ $5769 / \mathrm{s} 1$. 
Author Contributions: A.D.-C. and N.C.-P.: investigation and writing-original draft preparation. C.M.-P. and C.A.-S. formal analysis, resources, writing-review and validation. D.M.-C. and E.R.-C. conceptualization, formal analysis, writing — review and editing, supervisión, funding acquisition and project administration.

Funding: This work was funded by the Departamento Administrativo de Ciencia, Tecnología e InvestigaciónCOLCIENCIAS [Administrative Department of Science, Technology and Research] and the University of Cartagena, Grant 1107-569-33704 and project Actas 013-2017/011-2017. The funders had no role in study design, data collection, and analysis, decision to publish, or preparation of the manuscript. The proteomic analysis was performed in the Proteomics Unit at the Complutense University of Madrid that belongs to ProteoRed, PRB2-ISCIII, supported by grant PT13/0001.

Acknowledgments: The authors thank the University of Cartagena, Program to support Research Groups (2017-2018) and project 025-2015. The authors would like to thank Judith Rodriguez Cavallo for her technical assistance at the Analytical Chemistry and Biomedicine Labs, and Gregorio Young Castro for his support in $\mathrm{Hb}$ electrophoresis. To Sara Robledo for her kind donation of the P. falciparum clone 3D7. To Lola Gutierrez and Maria Luisa Hernáez of the Complutense University (Madrid) for the proteomic analysis and to Jorge Méndez Pacheco and Maria Alejandra Martinez for checking the spelling.

Conflicts of Interest: The authors declare no conflict of interest.

\section{References}

1. Cyrklaff, M.; Sanchez, C.P.; Frischknecht, F.; Lanzer, M. Host actin remodeling and protection from malaria by hemoglobinopathies. Trends Parasitol. 2012, 28, 479-485. [CrossRef] [PubMed]

2. Modell, B.; Darlison, M. Global epidemiology of haemoglobin disorders and derived service indicators. Bull World Health Org. 2008, 86, 480-487. [CrossRef] [PubMed]

3. Huttle, A.; Maestre, G.E.; Lantigua, R.; Green, N.S. Sickle cell in Latin America and the United States [corrected]. Pediatr. Blood Cancer 2015, 62, 1131-1136. [CrossRef] [PubMed]

4. Piel, F.B.; Patil, A.P.; Howes, R.E.; Nyangiri, O.A.; Gething, P.; Dewi, M.; Temperley, W.H.; Williams, T.N.; Weatherall, D.J.; Hay, S.I. Global epidemiology of sickle haemoglobin in neonates: A contemporary geostatistical model-based map and population estimates. Lancet 2013, 381, 142-151. [CrossRef]

5. Gong, L.; Parikh, S.; Rosenthal, P.J.; Greenhouse, B. Biochemical and immunological mechanisms by which sickle cell trait protects against malaria. Malar. J. 2013, 12, 317. [CrossRef]

6. Cholera, R.; Brittain, N.J.; Gillrie, M.R.; Lopera-Mesa, T.M.; Diakité, S.A.; Arie, T.; Krause, M.A.; Guindo, A.; Tubman, A.; Fujioka, H.; et al. Impaired cytoadherence of plasmodium falciparum-infected erythrocytes containing sickle hemoglobin. Proc. Natl. Acad. Sci. USA 2008, 105, 991-996. [CrossRef]

7. Lang, P.A.; Kasinathan, R.S.; Brand, V.B.; Duranton, C.; Lang, C.; Koka, S.; Shumilina, E.; Kempe, D.S.; Tanneur, V.; et al. Accelerated clearance of Plasmodium-infected erythrocytes in sickle cell trait and annexin-A7 deficiency. Cell. Physiol. Biochem. 2009, 24, 415-428. [CrossRef]

8. LaMonte, G.; Philip, N.; Reardon, J.; Lacsina, J.R.; Majoros, W.; Chapman, L.; Thornburg, C.D.; Telen, M.J.; Ohler, U.; et al. Translocation of sickle cell erythrocyte microRNAs into Plasmodium falciparum inhibits parasite translation and contributes to malaria resistance. Cell Host Microbe 2012, 12, 187-199. [CrossRef]

9. Ferreira, A.; Marguti, I.; Bechmann, I.; Jeney, V.; Chora, A.; Palha, N.R.; Rebelo, S.; Henri, A.; Beuzard, Y.; Soares, M.P. Sickle hemoglobin confers tolerance to Plasmodium infection. Cell 2011, 145, 398-409. [CrossRef]

10. Becker, K.; Tilley, L.; Vennerstrom, J.L.; Roberts, D.; Rogerson, S.; Ginsburg, H. Oxidative stress in malaria parasite-infected erythrocytes: Host-parasite interactions. Int. J. Parasitol. 2004, 34, 163-189. [CrossRef]

11. Contreras-Puentes, N.; Rodríguez-Cavallo, E.; Méndez-Cuadro, D. Membrane protein carbonylation of Plasmodium falciparum infected erythrocytes under conditions of sickle cell trait and G6PD deficiency. Mol. Biochem. Parasitol. 2019, 227, 5-14. [CrossRef] [PubMed]

12. Mendez, D.; Linares, M.; Diez, A.; Puyet, A.; Bautista, J.M. Stress response and cytoskeletal proteins involved in erythrocyte membrane remodeling upon Plasmodium falciparum invasion are differentially carbonylated in G6PD A- deficiency. Free Radic. Biol. Med. 2011, 50, 1305-1313. [CrossRef] [PubMed]

13. Fedorova, M.; Bollineni, R.C.; Hoffmann, R. Protein carbonylation as a major hallmark of oxidative damage: Update of analytical strategies. Mass Spectrom. Rev. 2014, 33, 79-97. [CrossRef] [PubMed]

14. Silva, D.G.H.; Belini Junior, E.; de Almeida, E.A.; Bonini-Domingos, C.R. Oxidative stress in sickle cell disease: An overview of erythrocyte redox metabolism and current antioxidant therapeutic strategies. Free Radic. Biol. Med. 2013, 65, 1101-1109. [CrossRef] [PubMed] 
15. Archer, N.M.; Petersen, N.; Clark, M.A.; Buckee, C.O.; Childs, L.M.; Duraisingh, M.T. Resistance to Plasmodium falciparum in sickle cell trait erythrocytes is driven by oxygen-dependent growth inhibition. Proc. Natl. Acad. Sci. USA 2018, 115, 7350-7355. [CrossRef]

16. Ueda, Y.; Bookchin, R.M. Effects of carbon dioxide and $\mathrm{pH}$ variations in vitro on blood respiratory functions, red blood cell volume, transmembrane $\mathrm{pH}$ gradients, and sickling in sickle cell anemia. J. Lab. Clin. Med. 1984, 104, 146-159.

17. Radfar, A.; Méndez, D.; Moneriz, C.; Linares, M.; Marín-García, P.; Puyet, A.; Diez, A.; Bautista, J.M. Synchronous culture of Plasmodium falciparum at high parasitemia levels. Nat. Protoc. 2009, 4, 1899-1915. [CrossRef]

18. Kavishe, R.A.; Koenderink, J.B.; Alifrangis, M. Oxidative stress in malaria and artemisinin combination therapy: Pros and Cons. FEBS J. 2017, 284, 2579-2591. [CrossRef]

19. Radfar, A.; Diez, A.; Bautista, J.M. Chloroquine mediates specific proteome oxidative damage across the erythrocytic cycle of resistant Plasmodium falciparum. Free Radic. Biol. Med. 2008, 44, 2034-2042. [CrossRef]

20. Alvear, C.C.; Barboza, M.; Viola-Rhenals, M.; Moneriz, C.; Araque, L.M. Pilot study of hemoglobinopathies in newborns of the Rafael Calvo maternity clinic of Cartagena, Colombia. Colomb. Med. 2012, 43, 196-199.

21. Duran, C.L.; Morales, O.L.; Echeverri, S.J.; Isaza, M. Beta globin haplotypes in hemoglobin S carriers in Colombia. Biomedica 2012, 32, 103-111. [CrossRef] [PubMed]

22. Wehr, N.B.; Levine, R.L. Quantitation of protein carbonylation by dot blot. Anal. Biochem. 2012, 423, $241-245$. [CrossRef] [PubMed]

23. Atamna, H.; Ginsburg, H. Origin of reactive oxygen species in erythrocytes infected with Plasmodium falciparum. Mol. Biochem. Parasitol. 1993, 61, 231-241. [CrossRef]

24. Mohan, K.; Ganguly, N.K.; Dubey, M.L.; Mahajan, R.C. Oxidative damage of erythrocytes infected with Plasmodium falciparum. An in vitro study. Ann. Hematol. 1992, 65, 131-134. [CrossRef]

25. Allen, S.M.; Lim, E.E.; Jortzik, E.; Preuss, J.; Chua, H.H.; MacRae, J.I.; Rahlfs, S.; Haeussler, K.; Downton, M.T.; et al. Plasmodium falciparum glucose-6-phosphate dehydrogenase 6-phosphogluconolactonase is a potential drug target. FEBS J. 2015, 282, 3808-3823. [CrossRef]

26. Scopes, D.A.; Bautista, J.M.; Vulliamy, T.J.; Mason, P.J. Plasmodium falciparum glucose-6-phosphate dehydrogenase (G6PD)-the N-terminal portion is homologous to a predicted protein encoded near to G6PD in Haemophilus influenzae. Mol. Microbiol. 1997, 23, 847-848. [CrossRef]

27. Mendez, D.; Hernáez, M.L.; Kamali, A.N.; Diez, A.; Puyet, A.; Bautista, J.M. Differential carbonylation of cytoskeletal proteins in blood group $\mathrm{O}$ erythrocytes: Potential role in protection against severe malaria. Infect. Genet. Evol. 2012, 12, 1780-1787. [CrossRef]

28. Akide-Ndunge, O.B.; Tambini, E.; Giribaldi, G.; McMillan, P.J.; Müller, S.; Arese, P.; Turrini, F. Co-ordinated stage-dependent enhancement of Plasmodium falciparum antioxidant enzymes and heat shock protein expression in parasites growing in oxidatively stressed or G6PD-deficient red blood cells. Malar. J. 2009, 8, 113. [CrossRef]

29. Atamna, H.; Pascarmona, G.; Ginsburg, H. Hexose-monophosphate shunt activity in intact Plasmodium falciparum-infected erythrocytes and in free parasites. Mol. Biochem. Parasitol. 1994, 67, 79-89. [CrossRef]

30. Linares, M.; Antonio, P.; Amalia, D.; José M., B. Oxidative Stress and Protein Carbonylation in Malaria. In Protein Carbonylation: Principles, Analysis, and Biological Implications; Ros, J., Ed.; John Wiley \& Sons, Inc.: Hoboken, NJ, USA, 2017; pp. 131-166.

31. Grover, M.; Chaubey, S.; Ranade, S.; Tatu, U. Identification of an exported heat shock protein 70 in Plasmodium falciparum. Parasite 2013, 20, 2. [CrossRef]

32. Baldi, D.L.; Andrews, K.T.; Waller, R.F.; Roos, D.S.; Howard, R.F.; Crabb, B.S.; Cowman, A.F. RAP1 controls rhoptry targeting of RAP2 in the malaria parasite Plasmodium falciparum. EMBO J. 2000, 19, 2435-2443. [CrossRef] [PubMed]

33. Beeson, J.G.; Drew, D.R.; Boyle, M.J.; Feng, G.; Fowkes, F.J.; Richards, J.S. Merozoite surface proteins in red blood cell invasion, immunity and vaccines against malaria. FEMS Microbiol. Rev. 2016, 40, 343-372. [CrossRef] [PubMed]

34. Ardeshir, F.; Flint, J.E.; Richman, S.J.; Reese, R.T. A 75 kd merozoite surface protein of Plasmodium falciparum which is related to the $70 \mathrm{kd}$ heat-shock proteins. EMBO J. 1987, 6, 493-499. [CrossRef] [PubMed] 
35. Reithmeier, R.A.; Casey, J.R.; Kalli, A.C.; Sansom, M.S.; Alguel, Y.; Iwata, S. Band 3, the human red cell chloride/bicarbonate anion exchanger (AE1, SLC4A1), in a structural context. Biochim. Biophys. Acta 2016, 1858, 1507-1532. [CrossRef] [PubMed]

36. Pantaleo, A.; Ferru, E.; Giribaldi, G.; Mannu, F.; Carta, F.; Matte, A.; de Franceschi, L.; Turrini, F. Oxidized and poorly glycosylated band 3 is selectively phosphorylated by Syk kinase to form large membrane clusters in normal and G6PD-deficient red blood cells. Biochem. J. 2009, 418, 359-367. [CrossRef]

37. Voskou, S.; Aslan, M.; Fanis, P.; Phylactides, M.; Kleanthous, M. Oxidative stress in beta-thalassaemia and sickle cell disease. Redox. Biol. 2015, 6, 226-239. [CrossRef]

38. Petrov, D.; Zagrovic, B. Microscopic analysis of protein oxidative damage: Effect of carbonylation on structure, dynamics, and aggregability of villin headpiece. J. Am. Chem. Soc. 2011, 133, 7016-7024. [CrossRef]

39. Alviz-Amador, A.; Galindo-Murillo, R.; Pineda-Alemán, R.; Pérez-González, H.; Rodríguez-Cavallo, E.; Vivas-Reyes, R.; Méndez-Cuadro, D. 4-HNE carbonylation induces local conformational changes on bovine serum albumin and thioredoxin. A molecular dynamics study. J. Mol. Graph. Model. 2019, 86, $298-307$. [CrossRef]

40. Bradford, M.M. A rapid and sensitive method for the quantitation of microgram quantities of protein utilizing the principle of protein-dye binding. Anal. Biochem. 1976, 72, 248-254. [CrossRef]

41. Mesquita, C.S.; Oliveira, R.; Bento, F.; Geraldo, D.; Rodrigues, J.V.; Marcos, J.C. Simplified 2,4-dinitrophenylhydrazine spectrophotometric assay for quantification of carbonyls in oxidized proteins. Anal. Biochem. 2014, 458, 69-71. [CrossRef]

42. Levine, R.L.; Garland, D.; Oliver, C.N.; Amici, A.; Climent, I.; Lenz, A.G.; Ahn, B.W.; Shaltiel, S.; Stadtman, E.R. Determination of carbonyl content in oxidatively modified proteins. Methods Enzymol. 1990, 186, 464-478. [PubMed]

43. Sechi, S.; Chait, B.T. Modification of cysteine residues by alkylation. A tool in peptide mapping and protein identification. Anal. Chem. 1998, 70, 5150-5158. [CrossRef] [PubMed]

(C) 2019 by the authors. Licensee MDPI, Basel, Switzerland. This article is an open access article distributed under the terms and conditions of the Creative Commons Attribution (CC BY) license (http://creativecommons.org/licenses/by/4.0/). 